\title{
DETERMINATION OF A LONG-TERM OPTIMAL IRRIGATION STRATEGY FOR DRY BEANS IN PARANA STATE, BRAZIL
}

\author{
RT. de FARIA ${ }^{1,3}$; MV. FOLEGATTI'; J.A. FRIZZONE ${ }^{2}$ A.M. SAAD \\ 'LAPAR, Rod Celso Garcia Cid, km 375, CEP: 8600I-970-Londrnna, PR - Brazil. \\ ${ }^{2}$ Depto. de Engenharia Rural-ESALQ/USP, C.P 9, CEP: 13.418-900 - Piracicaba, SP - Brazil. \\ Bolsista do CNPq.
}

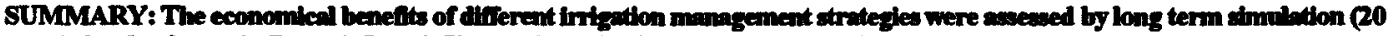

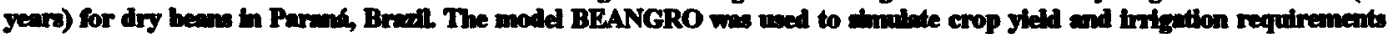
asuming eight levels of irrigation threhold (20 to $90 \%$ of the rematning soll avallable water in steps of 10\%), in addition to a level cosidering no hrigution. Net returm was the objective function to select the optemum irrigetion memagement stratesy, asouming fired and stochatic distributions of historical product price. The reoults shomed that yield was significantly mereased by imigation despite a high vartablity for all the chmolation strutegles, due to vartations on growth conditions over the years. Although the net return was highly vartable, $t \mathrm{t}$ was positve in $75 \%$ of the years for all strategies with threshold values higher then $30 \%$. The strutegy of hrigating the crop before the sol reaches $60 \%$ AW provided the maximum economical benefits. The high profit uing this improved strategs frutifies the practice of irrigation for beans in Parank

Descritores: irrigation, modeling, economical analysis

\section{ESTRATEGIA ÓTIMA DE IRRIGAÇÃO PARA FEIJÃO NO ESTADO DO PARANA, BRASIL}

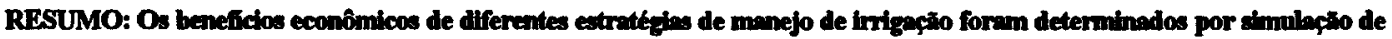
longo perfodo (20 enos) para a cultura do feljoeiro no Eatodo do Parme, Bran O modelo BEANGRO fol uvado para smular

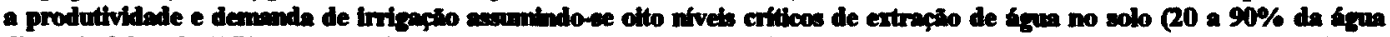

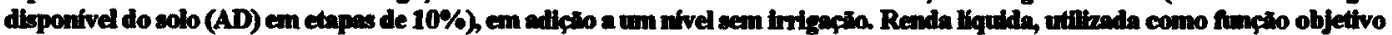

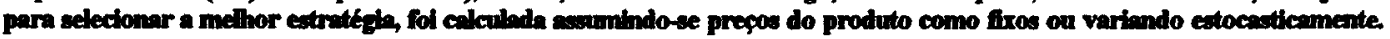

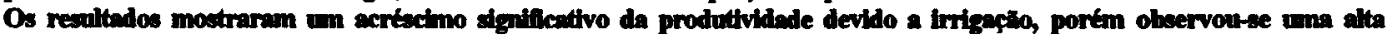
variahnidale de respoda em todos os nivels stmulados A renda Kquida foi tambem vartivel, portin positiva em $75 \%$ dos anos para todos as estrattegles em que se monteve o solo actma de 30\% AD. A estratégia de irrigar a cultura quando o solo atingir 60\% AD proporcionou o míxino retomo econômico. A renda Lquida proporcionada com o uso desta estratégia fustifica a aplicacizo de irrigactio em fetjoctro no Estodo do Parmé

Descritores: irrigafĩo, modellagem, andlise econômica

\section{INTRODUCTION}

The water is an essential agricultural resource that often limits crop yield. The optimization of plant water use, with the aim of maximizing and stabilizing productivity by the use of limited amount of the resource, is fundamental for decreasing risks, increasing economic returns, and minimizing environmental impact. This condition contributes for the sustainability of the farming system.

While irrigation leads to high and sTABLE yield levels, the economical benefits of this practice have to be established mostly for humid regions, due to expensive costs of equipment and system operation. Ultimately, this can be accomplished by comparing net returns obtained from irrigated and non-irrigated crops. In this comparison, the irrigated crop has to be conducted under optimal water management to achieve the potential yield with minimum requirements of water, energy, and labor. In this context, appropriate irrigation scheduling is a key factor to obtain improved irrigation management.

Irrigation schedule to optimize irrigation management may be assessed either by field experimentation or by simulation using models. Several experiments concerning critical irrigation thresholds were reported in the literature (Gallegos and Shibata, 1989; Sangakkara, 1994, Faria et al., 1997a). Optimum irrigation strategies for dry beans were determined in São Paulo, in two 
studies using land (Queiroz et al., 1996) and water (Calheiros et al., 1996; Saad, 1996) as limiting factors. They used a crop-water production function derived from experiments to calculate net benefits of application of different irrigation depths, by means of a well established analytical method of economic analysis (English, 1990). The limitation of such a method is that, usually crop production functions are derived from only one specific year, and therefore, do not represent the variability on yield due to climatic variability over the long term for a given site. Furthermore, crop production functions relate yield as a function of seasonal water applied. Because the climatic conditions are different from year to year, seasonally applied water and yield also varies. As a result, there is an optimal seasonal irrigation depth for each year. Furthermore, such studies do not provide a practical recommendation of irrigation management, since the optimum seasonal applied water determined analytically is not a decision variable, but a consequence of a given irrigation policy adopted during the growing season.

Due to the high costs and expensive time commitment involved in surveys or field trials, in addition to the limited applicability of the results, crop models are more appropriate to perform long term analysis to estimate crop response to water and optimization of economical benefits of irrigation. Specific management practices may be replicated over a number of seasons, using either historical or synthetic weather data, so that the variability of performance can be measured (Harrison et al., 1989). Many published reports show the validity of using crop models for studying the effects of constraints on crop yield (Egli and Bruening, 1992; Muchow et al., 1991), to assess appropriate management (Bemando et al., 1988; Rogers and Elliot, 1989; Stockle and James, 1989) and design of irrigation systems (Heermann et al., 1974; von Bernuth et al., 1984).

Although models can be applied widely, significant benefits of the method is achieved in conditions of non traditional agricultural systems. This is the situation of dry beans in Parana, which is the major national producer in Brazil. Recently, the introduction of a new cultivar in the North of the State made possible the cultivation of beans during the fall, from March to June, in addition to the traditional growing season in the spring, from August to November. As an advantage, farmers can obtain higher profits either by growing two bean crops per year or by using this crop in rotation summer crops. However, due to high variability in rainfall, the crop growing during the fall is subject to a high risk of water deficit (Caramori et al.,1991). Furthermore, yield frustration can occur due to occasional frost in late May and June.

Since the economic return is the primary concern of most producers, irrigation can be used to increase and stabilize bean yields in Paraná if profits are sufficient to cover investment in irrigation equipment and operational costs of the practice. This information can be obtained by simulation using a bean growth model named BEANGRO, which was recently validated for Paraná (Faria et al., 1997b).

The objectives of this study were to assess a long term irrigation strategy for beans cultivated during the fall and spring in Paraná, by selecting threshold levels that maximize the expected net return in the long term, and determine the monetary benefits of irrigation, by estimation of the increase in net return in the no irrigated crop.

\section{MATERIAL AND METHODS}

Simulation model: BEANGRO V2.02 (Hoogenboom et al., 1994) is a mechanistic and deterministic model for simulation of the developmental and growth processes of a bean plant in daily time steps. The model predicts, among several parameters, the duration of the phenological stages, biomass accumulation and grain yield for a specific cultivar, as a function of different soil types, climatic conditions, and crop management. The inputs include soil characteristics, climate parameters, plant coefficients, and crop management practices described in the minimum data set, acconding to the IBSNAT standard inputs/output format (IBSNAT, 1990). Cultivars are represented in the model by a set of coefficients (genetic coefficients) ideally derived from field calibration. Those coefficients describe the / characteristics of a given genotype, such as agronomic traits, critical thresholds for duration of vegetative and reproductive growth, and sensitivity to photoperiod and temperature. The simulation of phenology is based on definition of different crop stages. A stage is considered to occur when a specific photothermal accumulator reaches the critical threshold defined in the genetic coefficients. Biomass is partitioned to the different organs and its accumulation is given by the 
photosynthesis process, which depends on light interception. Those processes ane affected by either photoperiod, temperature, water stress, or nitrogen stress.

BEANGRO has an one-dimensional soil water balance submodel described by Ritchie (1985), in which water either from precipitation or irrigation infiltrates in the top layer after subtraction of runoff. Empirical procectures are used to calculate soil water flow upwards and downwards through the profile. Potential evapotranspiration and soil water availability govem the extraction of water by evaporation from the top soil layer $(0.5 \mathrm{~cm})$ and by transpiration from the root zone. Potential evapotranspiration is partitioned into transpiration and soil evaporation. Transpiration is proportional to the intercepted energy on the crop canopy and soil evaporation depends on the energy that reaches the soil surface. They are affected by the leaf area index, soil albedo, and soil water content. Under low soil moisture content or high root resistance, root water uptake is decreased and transpiration is reduced. Water stress is accounted for relative stress factors to reduce photosynthesis and expansive growth, and to increase biomass partitioning to the roots.

Simulation procedures: The climatic inputs required in BEANGRO were obtained from the IAPAR weather station in Londrina-PR (Latitude $23^{\circ}$ 27', Longitude 51'57'). The region has a subtropical humid climate characterized by hot summer and cool winter with lower precipitation and occasional frosts from June to August. Roughly two-thirds of the 1,200 to $1,900 \mathrm{~mm}$ annual precipitation falis in the summer, from October to March. Dry spelis of 10 days to 1 month are a common feature during the growing seasons, mostly for beans when cultivated either during the fall or spring. During those growing seasons, minimum mean temperatures range from $11^{\circ} \mathrm{C}$ to $15^{\circ} \mathrm{C}$ and maximum mean temperatures from $23^{\circ} \mathrm{C}$ to $27^{\circ} \mathrm{C}$.

Climatic parameters included 20 year historical records of daily maximum and minimum temperatures, wind velocity, sunshine hours, relative humidity, and precipitation. Those parameters were used to calculate the potential evapotranspiration by the FAO Penmin method.

The soil inputs used in BEANGRO (TABIE 1) were available from field analysis of a Latossolo Roxo (Typic Haplorthox) at the IAPAR Experimental Station in Londrina (Faria et al., 1994). This is a representative soil of the study area, characterized by clay contents of 40 to $60 \%$, deep profiles, high infiltration, absent or deep water TABLE, and low organic matter content (less then $3 \%)$.

The genetic coefficients for a widely planted cultivar (IAPAR 57) were obtained from a previous calibration using field data over several planting dates and water regimes (Faria et al. 1997b). Crop management inputs included sowing at $0.5 \mathrm{~m}$ spacing and 12 plants. $\mathrm{m}^{-1}$, and fertilizer application using the formula 10-75-25 kg. $\mathrm{ha}^{-1}$ of $\mathrm{N}$, $\mathrm{P}_{2} \mathrm{O}_{3}$, and $\mathrm{K}_{2} \mathrm{O}$ at sowing and $25 \mathrm{~kg}^{-1} \mathrm{ha}^{-1}$ of $\mathrm{N}$ in two applications at 20 and 35 days after sowing.

Simulation treatments included two planting dates (March 15 and August 15) and eight levels of irrigation threshold (20 to $90 \%$ of the remaining soil available water (AW) in steps of $10 \%$ ) at a control depth of $30 \mathrm{~cm}$, in addition to a level considering non irrigation. Each strategy was simulated over the series of 20 independent growing seasons.

For the strategies using irrigation, initial soil moisture was set at field capacity for the whole profile and simulations started at the day of sowing. For the non inrigation strategy, the simulations started with $50 \%$ AW at two months before sowing under bare soil conditions to estimate initial soil moisture inputs. In the absence of experimental information for beans in this area of study, $50 \% \mathrm{AW}$ at $0-10 \mathrm{~cm}$ was taken as a critical level of soil moisture for crop emergence. If this criteria was not met before 15 days after March 15 and 30 days after August 15, the crop was not sown and yield was considered as zero. The assumption of extending planting period was based on the fact that delaying sowing further in the fall can increase risks of frost for the crop grown during the fill. The constraints for planting later than September 15 are the high temperatures coinciding with flowering after mid-October and more rainfall at harvest in December. In the simulations irrigation was assumed to be instantaneously and uniformly applied by a center-pivot system and water supply for irrigation was not limiting.

In the economical analysis, total costs of crop production ( $C_{t}$ in $R S . h^{-1}$ ) were represented as:

$$
C_{t}=C_{0}+C_{i}
$$

where, $C o$ is fixed cost associated to crop production and $C_{i}$ is irrigation cost (both in RS.hat). The component $C_{i}$ was given by Equation 2 : 


$$
C_{i}=C_{c}+C_{w} D
$$

where $C_{c}$ is capital cost related to investment in irrigation equipment ( $\left.R S . \mathrm{ha}^{-1}\right), \mathrm{C}_{\mathrm{w}}$ is operational costs of irrigation (RS.mm $\left.{ }^{-1}\right)$, and D is the seasonal depth of irrigation water $(\mathrm{mm})$.

Variable costs associated with increasing production were not considered, based on the assumption that crop received the same inputs and harvesting was charged per unit of area. The value of $C_{w}$ included the costs of water, energy and operational costs of water application. Those costs were as R\$ $410.00 \mathrm{ha}^{-1}$ for $\mathrm{Co}$ and RS $0.50 \mathrm{~mm}^{-1}$ for $C_{\text {w. }}$. They were calculated (IPT, 1994) from an average of several irrigation projects with centerpivot in Săo Paulo. Capital costs including depreciation over 10 years and interest of $12 \%$ per year were taken from a study of Frizzone et al. (1994) as R\$ $146.00 \mathrm{ha}^{-1}$, assuming average costs for typical areas irrigated with center-pivots in Bahia State.

Net retum, assumed as a management objective, was calculated as follows:

$$
N P=\max \left\{P Y_{(d, i)}-C_{t(d, i)}\right\}
$$

where $P$ is the product price (RS), $Y$ is the crop yield $\left(\mathrm{kg} \cdot \mathrm{ha}^{-1}\right), d$ is the irrigation threshold, and $i$ is the year of simulation.

Two analyses were performed assuming stochastic variation of the product price and fixed prices. In the first analysis, the product price was assumed to have a stochastic variation according to a triangular distribution with lower bound, upper bound, and mode equal to RS $0.46 \mathrm{~kg}^{-1}, \mathrm{RS} 1.81 \mathrm{~kg}^{-1}$, and RS $0.71 \mathrm{~kg}^{-1}$, respectively. Those parameters were estimated from historical prices of the commodity according to Preços Agricolas (1997). They were used to produce a price cumulative probability function (CPF), in addition to the yield cumulative distribution, which was made up of 20 replicates (simulated year), corresponding to the period of simulation. The quantity P.Y (d) in Equation 3 was calculated by combining $Y$ of each replicate with the inverse of the price analytical cumulative probability finction (CPF), using five equi-distant percentiles of the CPF (0th, 25th, 50th, 75th, and 100th), according to the procedure described by Thomton et al. (1994). The product $P_{(P)}, Y_{(d)}$, where $\mathrm{pr}$ is the probability corresponding to each percentile considered in the analysis, included a set of 20 replicates $\times 5$ prices, which was sorted to build a
CPF for the vector. The CPF for net return per hectare was then obtained by subtracting $C_{t}$ from revenue obtained from the P.Y CPF for pr from 0 to $100 \%$ in steps of $10 \%$.

In the second analysis, retums were calculated for product prices fixed at the lower bound, upper bound and median of the price distribution used in the first analysis. The results of crop yield, seasonal irrigation depth and applications, and net return for each strategy over the simulation period were ranked to build a cumulative probability distribution and results were presented for percentiles $10,25,50,75$, and 90 .

\section{RESULTS AND DISCUSSION}

The simulation results of yield, seasonal inigation depth, and water application for the two cropping seasons over the 20 year period are given in Figure 1. For both growing seasons, yield significantly increased with the increase of the irrigation threshold. The results show little response when the crop was irrigated at $20 \%$ AW, a sharp increase from 20 to $50 \% \mathrm{AW}$, and then the curves reach a maximum for irrigation thresholds from 50 to $90 \%$.

Although irrigation has been considered as a method to provide stability to the crop production to decrease yield variability, the results in Figure 1 show the contrary. A high variation was observed for all simulated treatments. This indicates that water is not the only growth limiting factor. Variations in temperature, solar radiation, and distribution of precipitation also play a role, besides other important factors not considered by the model, such as soil nutrients other then nitrogen, pests, diseases, etc.

The differences in climatic conditions of the two growing seasons caused also differences in yield. For the strategies using irrigation, the lower attainable yields for the crop sown in March were attributed to sub optimal temperature and solar radiation during May and June, as compared with the yields siniulated for the crop grown in the spring. This is illustrated by the results in Figure 1, in which, for irrigation threshold above $60 \% \mathrm{AW}$, expected yields for the crop sown in August are above $2000 \mathrm{~kg} \cdot \mathrm{ha}^{-1}$ in $90 \%$ of the years $(p=10)$ and can reach 2700 $\mathrm{kg} \cdot \mathrm{ha}^{-1}$ in $10 \%$ of the years $(\mathrm{p}=90)$. Using the same strategy in the fall, the resultant expected yields are less than $2100 \mathrm{~kg} \cdot \mathrm{ha}^{-1}$ in $90 \%$ of the years $(p=90)$ and no yield is expected in $10 \%$ of the years $(p=10)$. 
TABLE 1. Soil inputs used in BEANGRO.

\begin{tabular}{|c|c|c|c|c|c|c|}
\hline \multicolumn{7}{|c|}{ Profile parameters" } \\
\hline \multirow[t]{2}{*}{ Depth (cm) } & \multicolumn{6}{|l|}{ Parameter. } \\
\hline & $\begin{array}{l}\text { SLL } \\
\left(\mathrm{cm}^{3} \cdot \mathrm{cm}^{-3}\right)\end{array}$ & $\begin{array}{l}\text { SDUL } \\
\left(\mathrm{cm}^{3} \cdot \mathrm{cm}^{-3}\right)\end{array}$ & $\begin{array}{l}\text { SSAT } \\
\left(\mathrm{cm}^{3} \cdot \mathrm{cm}^{-3}\right)\end{array}$ & $\begin{array}{l}\text { SBDM } \\
\mathrm{g.cm}^{-3}\end{array}$ & $\begin{array}{l}\text { SSKS } \\
\mathrm{cm} \cdot \mathrm{h}^{-1}\end{array}$ & SRGF \\
\hline $0-10$ & 0.20 & 0.35 & 0.43 & 1.1 & 1.9 & 1.00 \\
\hline $0-25$ & 0.27 & 0.38 & 0.43 & 1.0 & 1.9 & 0.25 \\
\hline $25-40$ & 0.27 & 0.38 & 0.43 & 1.0 & 1.9 & 0.25 \\
\hline $40-55$ & 0.27 & 0.36 & 0.43 & 1.0 & 1.9 & 0.10 \\
\hline $55-70$ & 0.27 & 0.36 & 0.43 & 1.0 & 1.9 & 0.05 \\
\hline $70-130$ & 0.27 & 0.36 & 0.43 & 0.9 & 1.9 & 0.00 \\
\hline \multicolumn{7}{|c|}{ Surface parameters" } \\
\hline \multicolumn{2}{|c|}{ Parameter } & Value & Parameter & Value & Parameter & Value \\
\hline \multicolumn{2}{|c|}{ SALB } & 0.14 & SLDR & 0.80 & SLNF & 1.0 \\
\hline \multicolumn{2}{|l|}{ SLUI } & 7.7 & SLRO & 76 & SLPF & 0.80 \\
\hline
\end{tabular}

${ }^{1}$ SLL, SDUL and are respectively soil moisture lower limit, upper limit and saturation, SBDM is soil bulk density, SSKS is soil saturated hydraulic conductivity, SRGF is soil root growth factor, SALB is soil albedo (fraction), SLU1 is soil evaporation factor (mm), SLDR is soil drainage rate (fraction.day ${ }^{-1}$ ), SLRO is SCS runoff curve number, SLNF soil nitrogen mineralization factor, and SLPF is photosynthesis factor.

Yields equal to zero were simulated in response to the failure to accomplish the crop cycle, due to frost, or to complete crop establishment, when of soil moisture was below the critical level at sowing. This occurred in $10 \%$ of the years for all strategies sown on March 15 and in $30 \%$ of the years for the non irrigated crop sown on August 15. The criteria for crop emergence in the non-imigated crop (established as $50 \% \mathrm{AW}$ at $0-10 \mathrm{~cm}$ ) was not met in 3 of 20 years in the fall and in 6 of 20 years in the spring. In addition, frost occurring at the end of the growing season in the fall and at the beginning of the cropping period in the spring caused yield frustration in 3 years and in one year of 20 years, respectively.

Irigation requirements to maintain soil moisture above the critical level established in each strategy increased exponentially as threshold was increased from 20 to $90 \%$ AW (Figure 1). Taking $60 \% \mathrm{AW}$ as an example, expected irrigation depths vary, for percentiles 10 and 90 , from 120 to $230 \mathrm{~mm}$, in 6 to 11 applications of about $20 \mathrm{~mm}$, for the fall growing season, and from 230 to $330 \mathrm{~mm}$, in 11 to 15 applications, for the crop grown during the spring. Those results agree with depth and number of application observed in field experiments conducted in the study area, as reported by Faria et al. (1997a), and are in accordance to the results obtained for other regions in Brazil, as reported by Saad (1996), Queiroz et al. (1996), and Calheiros et al. (1996).

The range of variation in each irrigation policy is a result of different needs in water supply over the years, caused by variability in rainfall distribution and atmospheric demand. The higher application depth in the spring was a result of more elevated temperatures during October and November, increasing evapotranspiration, compared to mild temperatures and resulting low atmospheric demand during the fall. High irrigation thresholds required more frequent irrigation, inducing higher loss of water by evaporation from the soil surface, runoff, and drainage, as it was given by the simulation of the components of the water balance (results not shown). This can impact environment due to soil erosion and leaching of nutrients and pesticides. In addition, frequent applications of irrigation can cause leaves and soil to be wet for longer periods, increasing chances for incidence of crop diseases.

The stochastic variation on crop yield (due to years) and prices made net return uncertain for all simulation strategies and growing seasons, as given by a variation on a wide range, as shown in Figure 2. The lower bound represents the combination of low prices and unfavorable years, while the upper bound 

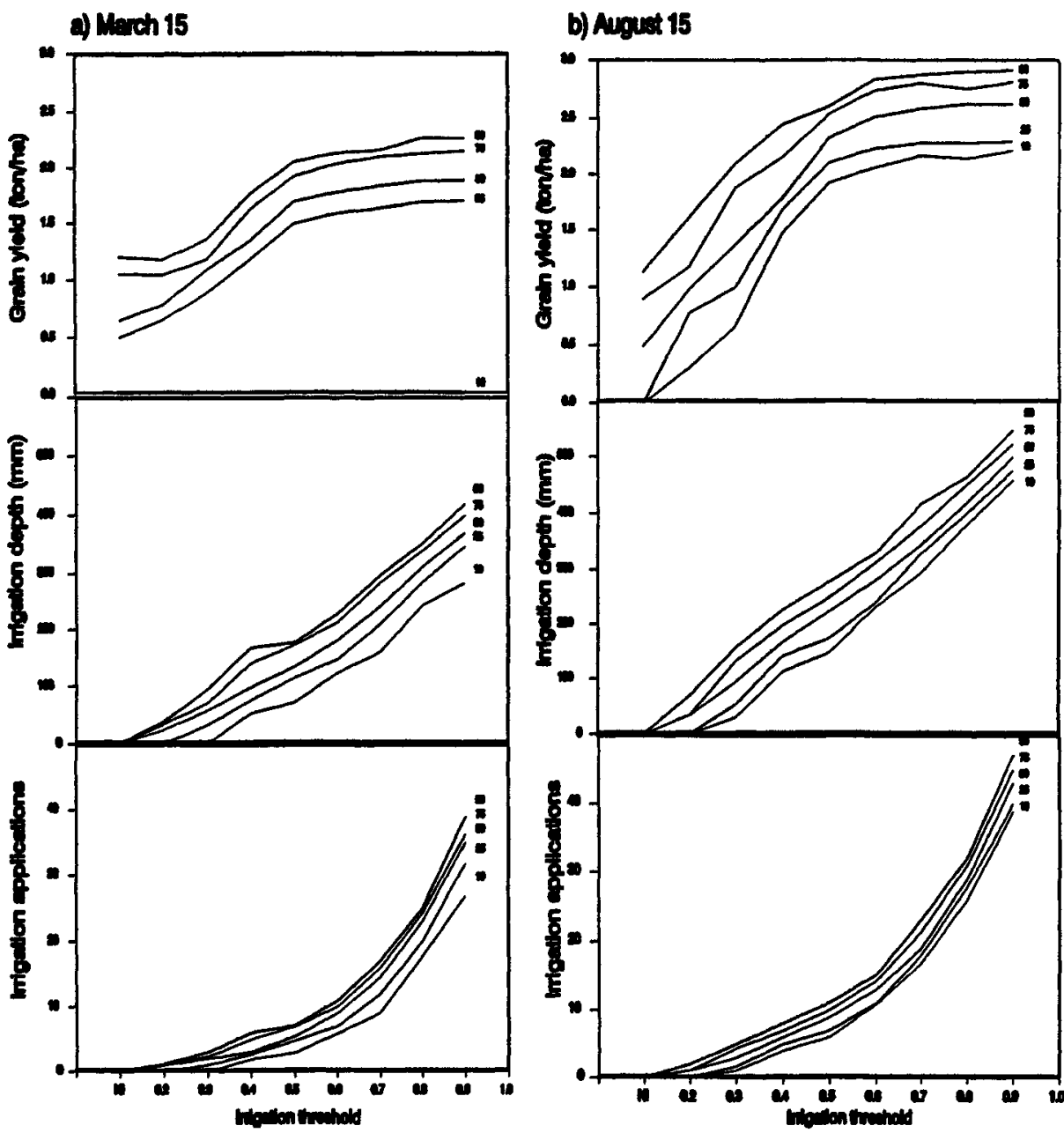

Figure 1 - Distribution of simulated grain yield, seasonal irrigation depth and irrigation application for different irrigation strategies and planting dates.

is representative of high prices in years with good conditions for crop growth. Despite uncertain, net retum was positive for both growing seasons in $75 \%$ of the years if soil moisture was maintained above $30 \% \mathrm{AW}$ and increased significantly with increase in irrigation threshold up to 50 to $60 \% \mathrm{AW}$. For higher threshold levels the curves in Figure 2 show that no marked benefit can be expected. In addition, net economical benefits were higher for the simulations of the crop grown during the spring as a consequence of difference in yields, caused by differences in climatic conditions.
Negative economic returns occurred in $10 \%$ of the years for the simulations with crop grown during the fall because of frost late in the growing season. In this case, rectuction in net income was higher for the irrigated crop because of the additional costs of irrigation. Figher risks to obtain posit returns was simulated for the non irrigated crop in the spring. Therefore, net return was less than $R \$ 450 \mathrm{ha}^{-1}$ in $75 \%$ of the years and equal to or less than zero in about $50 \%$ of the years. This was either because crop was not established due to low soil moisture at sowing ( $30 \%$ of the years), and then no spending was 
a) March 15

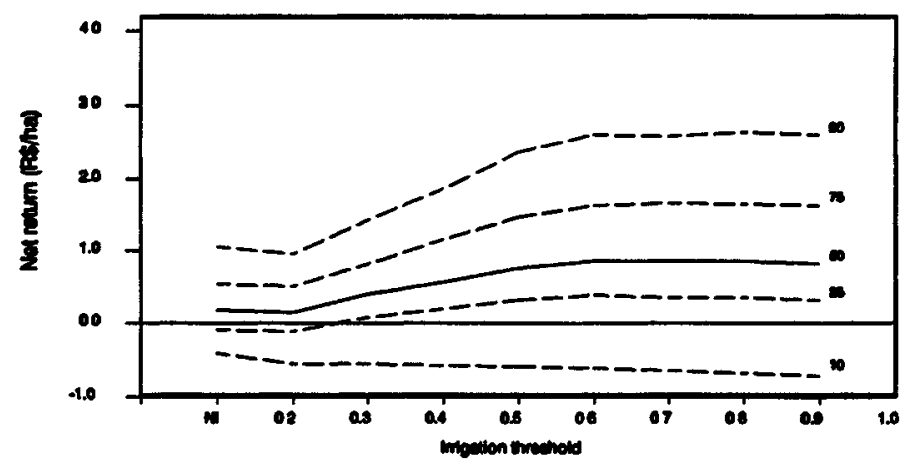

b) Auguet 15

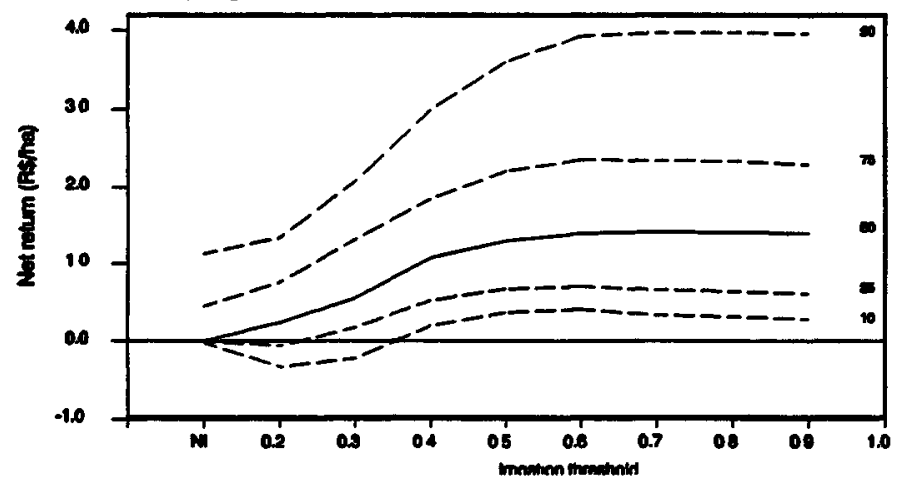

Figure 2 - Distribution of simulated net returns for different imigation thresholds and planting dates assuming stochastic variation of product price.

made, or yield was too low to cover costs for crop production (10\% of the years). This policy was better than irrigation at $20 \% \mathrm{AW}$, which gave in negative net returns in $25 \%$ of the years.

The analysis assuming fixed values of product price illustrates a common situation faced by farmers at the time to decide whether to grow beans or choose another crop. The results show the same trend as the previous analysis, but uncertainty in net return is significantly decreased when prices are given (Figure 3). This demonstrates how important is the role played by the price of the commodity, compared to attainable yield and costs, in determining profit. This conclusion agrees with the finding of Queiroz (1996). Therefore, when product price is low expected net return is less than RS $500 \mathrm{ha}^{-1}$ for all strategies, with high chances for negative profit at low irrigated or non irrigated crop. When the expected price is equal to the mode, farmers not using irrigation can expect net returns equal to or less than zero in $50 \%$ of the years. In this case, the use of irrigation with adoption of an appropriate threshold level can increase net return to levels above RS $250 \mathrm{ha}^{-1}$ and RS $500 \mathrm{ha}^{-1}$ in $75 \%$ of the years for the fall and spring growing seasons, respectively. Finally, when the product price is equal to the historical upper bound the activity is highly profitable, even for the non irrigated crop.

Based on the results presented above, irrigation at $60 \% \mathrm{AW}$ could be justified as the optimum irrigation strategy, in spite of slight increases in net retum for higher irrigation thresholds, in view of the lower demand in water, energy and number of irrigation applications during the cropping season. Adopting this strategy, the producer can expect a net retum above $\mathrm{RS} 350 \mathrm{ha}^{-1}$ 

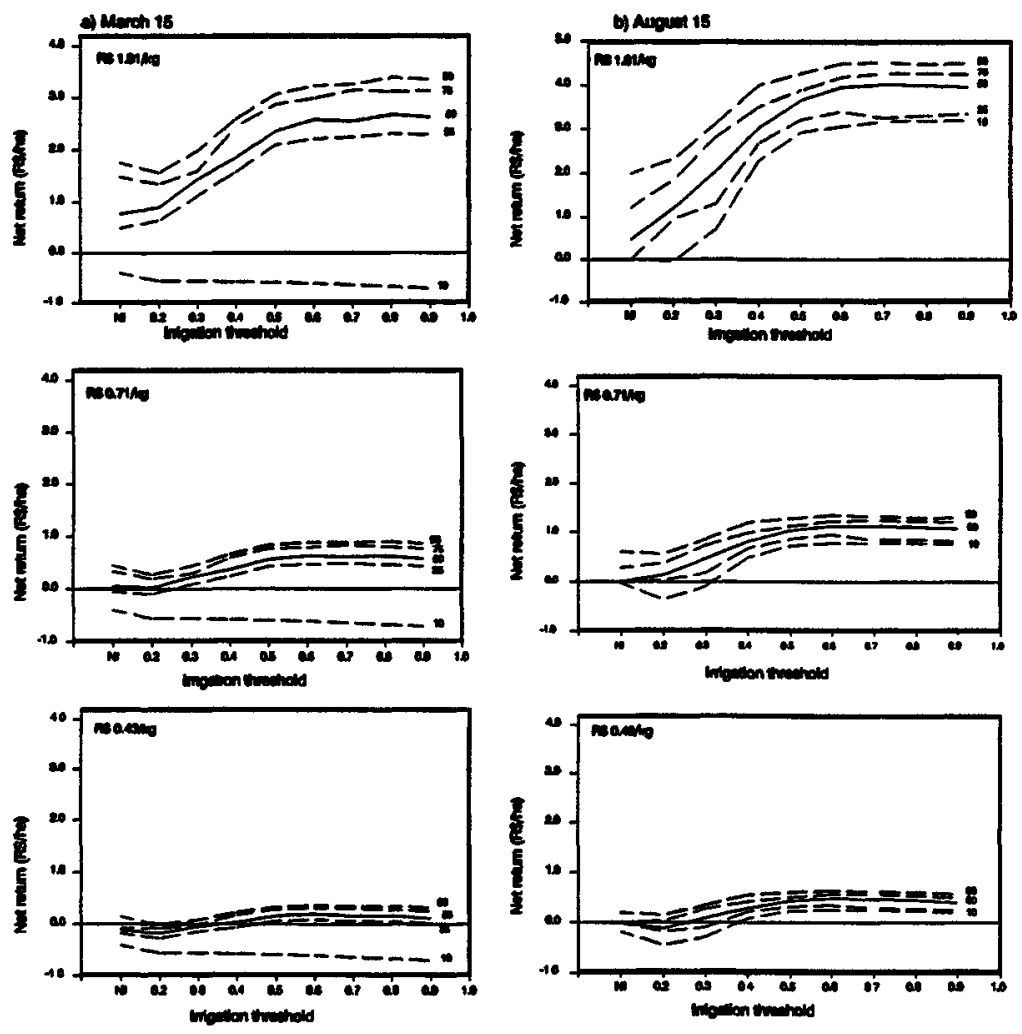

Figure 3 - Distribution of simulated net retums for different irrigation thresholds and planting dates assuming fixed product price.

with a probability of $75 \%(p=25)$ and up to $R S$ 2600 ha-1 with probability of $10 \%(p=90)$ for the crop sown in the fall. For the spring, expected returns can be as high as RS 3900 ha-1in 10\% of the years $(p=10)$ and above $r \$ 400$ ha-1 in $75 \%$ of the years.

The estimation of the benefits of using the improved irrigation strategy over the non irrigation strategy was based on the long term average and assuming that two crops can be grown per year. The average net return for the non irrigated crop over the 20 years was RS $324 \mathrm{ha}^{-1}$ and RS $130 \mathrm{ha}^{-1}$ for the fall and spring cropping seasons, respectively, with a total of R\$ $450 \mathrm{ha}^{-1} \cdot \mathrm{yr}^{-1}$. Taking $60 \% \mathrm{AW}$ as the optimum strategy, annual net return equal to RS 2853 $\mathrm{ha}^{-1} \cdot \mathrm{yr}^{-1}$ was calculated from the summation of the individual averages simulated for the fall and spring growing seasons (R\$ $1131 \mathrm{ha}^{-1}$ and $\mathrm{R} \$ 1722 \mathrm{ha}^{-1}$, respectively). The difference in annual net return equal to RS $2403 \mathrm{ha}^{-1} \cdot \mathrm{yr}^{-1}$ is the increase in net income due to irrigation using the optimal irrigation threshold. This value, which was about five times the net return of the non irrigated strategy, justifies the use of irrigation in Paraná in areas in which operational and capital costs are similar to the ones assumed in this analysis.

It is important to note that the benefits of irrigation are constrained also by other factors not considered by the simulation model. Among them, pest and diseases are the most important, since beans is very susceptible to various pathogens. Therefore, yields and net returns can be lower than the values calculated in the previous analysis, depending on the importance of other growth factors not accounted for in this analysis. 


\section{CONCLUSIONS}

The simulation of bean growth over a long term period assuming different strategies for timing of application of irrigation allows the following conclusions:

- The non irrigated crop is risky in Parand due to high variability in precipitation during the growing seasons,

- Irrigation can increase significantly crop yield, but variability is still high due to effects of other growth factors,

- The optimal long term irrigation benefit was obtained with irrigation at $60 \mathrm{AW}$;

- Irrigation can prevent negative profits in most cases, but net return is highly dependent on the product price;

- The high economical benefits of imigation, obtained by the use of the improved imigation strategy and by cultivation of beems in two seasons per year, justify the application of irrigation in Paranh.

\section{RETRRENCES}

BERNARDO, DJ.; NK. WHITTLESEY; KE. SAXTON; D.L. BASSET. Irigation optimization under limited water supply. Trumenctions of the ASAZ, v.31, p.712-719, 1988.

CAIHEIROS, C.B.M; J.E, QUEIROZ; J.A. FRIZZONE; P.C.S. PESSOA Estrutegias times do irigagao do feijoeiro: dqua como fator limiturte da productio. Pesquea Agropecuitrin Bracielin, v.31, n.7, p.509-515, 1996.

CARAMORI, P.H.; OUIVERA; D. de; FARIA, RT. de. frequencia de coomencia de perfodos com deficiencia bidrica (veranicas) no Estado do Paranl Boletion Técriico no 36. Instituto Agronćmico do Paranh, Londrina-PR, 1991. 40p.

EGL, D.B; BRUENING, L Planting date and soybean yield: evaluation of environmental effects with a crop simulation model: SOYGRO. Agrienthural and Forest Meteorolos, v.62, p.19-29, 1992.

ENGLSH, M. Deficit inigation. I Analytical framework

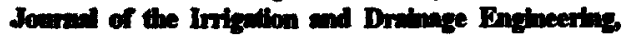
v.I16, n3, p.339-412, 1990.

FARIA, RT. dF. MADRAMOOTOO, C.A; BOISVERT, J.; S.; PRASHER Comparion of SWACROP and Veratile Boil Mointure Budget models in Brazil Cmmollim

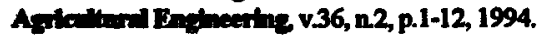

PARIA, RT. do OLIVEIRA, D. de; FOLEGATT, M.V. Potencial produtivo do fejpeiro no note do Parand em diferedes Gpocss de semeadura e regimes hidrioos. In: $X$ CONGRESSO BRASILETRO DE AGROMETEOROLOGIA, Piracicabe 1997a Anola (in press).

FARIA, RT. dE; OLIVETRA, D. \&; FOLBGATT, MV. Simulagio da fenologia e producilo do fejjociro pelo modelo BEANGRO. In: $X$ CONGRESSO BRASILEIRO DE AGROMETEOROLOGLA, Piracioube 1997b. Ande (in prose)

FRIZZONE, J.A; BOTREL, T.A; FRETAS, H.A.C. Antlise comperetiva dos cuetos do irrigatio por pivb-artral en cultura de feijlo, utilizando energia elcurica e bleo diesel. Bugenimite Rurri, v.5, n1, p.24-53, 1994.

GAIJ EGOS, J.AA; SHIBATA, J.K. Efiect of water stress on gowth and yield of indelemined dybean (Phaseolus vulgaris) allivars Feld Crops Resenrch, v.20, p.81-93, 1989.

HARRISON, S.R; THORNTON, P.K; DENT, J.B. The role of simulation experimerts. Aprotechnologs Trmofer, v.9, p.10-11, 1989.

HERRMANN, D.F; SHUL, H; MCKELSON, RH. Carter pivot design capacities in Eevtem Colorudo. Jommol of the Irfigution and Drelnage Divition of the ASCZ 100(1R2), p.127-141, 1974.

HOOGENBODM, G.; WHITE, J.W.; JONES, J.W.; BOOTE, K.j; BOWEN, W.T.; PICKERNGG, N.B; BACHELOR, W.D. CROPGRO-Dy Bean In: Crop Models. DSSAT verion 3. IBSNAT, Hawaii, 1994.

HOWEL, T.A; COPELAND, K.S; SCHNEIDER, AD; DUSEK, D.A Sprinder irrigation management for com Southem Grat Plains. Tranactions of the ASAD, v.32, p.147-155, 1989.

IBSNAT. IBSNAT progress repot 1987-1990. International Benchmark Site Network for Agrotechnoly Transfer, Honoluhu, USA, 54 pp. 1990.

MUCHOW, R.C; HAMMER, G.L; CARBERRY, P.S. Optimising crop cultivar selection in response to climatic rick pp 235-162. In: Climetic Risk in Crop Production: Models and Management for the Semiarid Tropics and Subtropics. Eds. Muchow R.C. and J.A. Bellamy. C.A.B. Intemational, Wallingford, UK. 1991.

Prepos Agricolas ESALQ/USP, Piracicaba, n.126. 1997.

QUEIROZ, JE; CALHETROS, C.B.M.; PESSOA, P.C.S.; FRIZZONE, J.A Estratgias b́timas de inigagao do fejjociro: terra como fitor limitante da productio. Pesquisa Agropeconta Brecieire, v.31, n1, p.55-61, 1996. 
RITCHIE, J.T. A user-oriented model of soil water balance in wheat. In: DAY, W.; ATKIN, R.K. (eds.) Wheat growth and modeling. Plenum Publishing Corporation 1985. p.293-305.

ROGERS, D.H.; ELLIOT, R.L Irrigation scheduling using crop growth simulation, risk analysis, and weather forecast. Transactions of the ASAE, v.32, p.1669-1677, 1989.

SAAD, AM. O déficit de irrigação como estratégia de manejo da água em feijoeiro (Phaseolus vulgaris L). ESALQ/USP, Piracicaba, 1996. 146p.

SANGAKKARA, U.R. Growth, yield and nodule activity of Phaseolus vulgaris L as affected by soil moisture. Jourmal of Agronomy \& Crop Sclence, v.172, p.62-68, 1994.
STOCKLE, C.O.; JAMES, LG. Analysis of deficit irrigation strategies for com using crop growth simulation. Irrigation Science, v.10, p.85-98, 1989.

THORNTON, P.K; HOOGENBOOM, G.; HOOGENBOOM, G. A computer program to analyse single season crop model outputs. Agronomy Journal, v.86, n.5, p.860-868, 1994.

von BERNUTH, RD; MARTIN, D.L; GILLEY, J.R; WATTS, D.G. Irrigation system capacities for com production in Nebraska. Transactions of the ASAE, v.27, p.419-424, 1984.

Recebido para publicação em 20.04 .97 Aceito para publicação em 22.05.97 